\title{
The Chilean Winter: A Student Revolution
}

\section{Sam Pickett}

Faculty Mentor: Dr. Andrés Guzmán, Department of Spanish and Portuguese, Indiana University Bloomington

\begin{abstract}
The 2011 Chilean Winter was a student movement that fought to end the rampant inequality found in the nation's neoliberal education policies, which found their origins in the reforms enacted during the 1980s by Chilean dictator General Augusto Pinochet. In response to the nation's economic crisis, he attempted to cut government spending by decentralizing and privatizing the education system. The results were largely unfavorable; Chilean education came to be known for its socioeconomic stratification, unequal schools, and its exorbitantly expensive universities. Despite the undoubtedly negative outcome of Pinochet's policies, they remained relatively untouched until student movements in 2006 and 2011 began to challenge them. Although almost all of the issues that the 2011 Chilean Winter addressed were the result of Pinochet's policies, it would be incorrect to claim that the students were protesting his reforms. Instead, the movement was a reaction to the failure of the nation's post-dictatorship governments, the Concertación coalition and right-centrist presidency of Sebastián Piñera, to restructure Chile's neoliberal education system despite its numerous problems. This work aims to disprove the erroneous view of many newspapers and academic journals that the student movement was caused directly by Pinochet's policies. In other words, I wish to separate protest against the legacy of the Pinochet reforms-that is the current system-from protest against the reforms themselves. The work will be divided into two main sections. The first section will focus on demonstrating the lasting impact of Pinochet's education programs, with a particular emphasis on statistical studies performed by other researchers. The second section will be devoted to analyzing the roots of the 2011 student movement. This part of the investigation will focus on rhetoric from the students themselves, especially movement leader Camila Vallejo.
\end{abstract}

KEYWORDS: Chile, student movement, education reform, General Augusto Pinochet, Camila Vallejo, protests

A s sinister music fills the air, Chilean students, dressed elaborately as zombies, clamor to fill the square outside of the presidential palace, known as La Moneda. The protesters thrash about, perfectly portraying the living dead as they begin to fall into formation. Spectators eagerly await the culmination of this odd display, cameras at the ready. It is at this moment that the distinct beat of "Thriller," the hit Michael Jackson song, blares from the speakers. Thousands of students snap into position and begin a coordinated dance. The crowd roars its approval. It is June $25,2011 .^{1}$

While this demonstration may strike the common observer as innocent, it represented an important part of the 2011 Chilean Winter ${ }^{2}-$ a student movement that fought to end the rampant inequality found in the nation's neoliberal education system.

\section{INTRODUCTION}

The educational policies that so frustrated these protesters found their origins in the reforms enacted during the 1980s by Chilean dictator General Augusto Pinochet. In response to the nation's economic crisis, he attempted to cut government spending by decentralizing and privatizing the education system. The results were largely unfavorable; Chilean education came to be known for its socioeconomic stratification, unequal schools, and its exorbitantly expensive universities. Despite the undoubtedly negative outcome of Pinochet's policies, they remained relatively untouched until student movements in 2006 and 2011 began to challenge them. Although almost all of the issues that the 2011 Chilean Winter addressed were the result of Pinochet's policies, it would be incorrect to claim that the students were protesting his reforms. Instead, the movement was a reaction to the failure of the nation's post-dictatorship governments, the Concertación coalition and right-centrist presidency of Sebastián Piñera, to restructure Chile's neoliberal education system despite its numerous problems.

Reuters, "Chile Thriller Protest," Filmed [June 2011], YouTube video, 1:06, Posted [June 2011], https://www.youtube.com/watch?v=sVjqtxGr1nY.

The name "Chilean Winter" was a reference to the "Arab Spring" that was occurring in the Middle East around the same time.
Researching the relationship between Pinochet's reforms, their effects, and the 2011 student movement is important because education reform has remained a prominent issue in Chilean politics for over 30 years. In fact, center-leftist President Michelle Bachelet won the 2013 election in large part because of her promises to transform the Chilean education system. The failure of her predecessor, Sebastián Piñera, to reorganize the system and adequately deal with the 2011 Chilean Winter left him with a 34 percent approval rating and contributed to his party's severe electoral defeat, 68 percent to 38 percent. ${ }^{3}$ Thus, the clear importance of education to Chile's population, as well as its elected leaders, invites further investigation into the nation's educational issues and how students have addressed them in the past.

There are two main factors that make this paper unique. First, most authors focus exclusively on either the student movement may briefly mention a relationship between the two, none of them go into the same depth that this paper does. Secondly, this analysis aims to disprove the erroneous perspective of many newspapers and academic journals that the student movement was caused directly by Pinochet's policies. Instead, this investigation works to separate protest against the legacy of the Pinochet reforms-that is, the current system-from protest against the reforms themselves.

The work will be divided into two main sections. The first section will focus on demonstrating the lasting impact of Pinochet's education programs, with a particular emphasis on statistical studies performed by other researchers. The second section of the research will be devoted to analyzing the roots of the 2011 student movement. This part of the investigation will focus on rhetoric from the students themselves, especially movement leader Camila Vallejo.

\footnotetext{
${ }^{3}$ Dan Collyns, "Bachelet pledges radical constitutional reforms after winning Chilean election," The Guardian, December 2013, http://www.theguardian.com/world/2013/ dec/16/chile-president-elect-michelle-bachelet-election-reforms.
} or the effects of Pinochet's education reforms. While the writers 


\section{PINOCHET'S POLICIES AND THEIR CONSEQUENCES}

Prior to the 1980s, the Chilean Ministry of Education was responsible for almost all aspects of the education system, including teacher salaries, curriculum, and infrastructure. ${ }^{4}$ However, General Augusto Pinochet's decentralization reforms handed over control of local schools to municipal governments, who were now in charge of everything except for the national curriculum. ${ }^{5}$ Furthermore, he privatized the system by establishing "a vouchertype government subsidy available for use in both private and public municipal schools, which are distributed in numbers directly proportional to the size of a school's enrollment." ${ }^{6}$ As a result, when students changed schools, so did their money. Schools were therefore expected to compete for students because the government believed that parents would send their children to the best schools with the best teachers. This marketization of education was supposed to raise the quality of Chilean schools by giving citizens more control over their communities and weeding out sub-par schools. ${ }^{7}$

Pinochet's reforms, however, had a different effect than was intended. Three types of schools formed: municipal schools, funded solely by local governments; private schools, subsidized in part by the government; and private, fee-paying schools, unfunded by the public. As a result of this decentralization, there was an $18 \%$ drop in federal spending on education. ${ }^{8}$ At the same time, there was a large increase in the number of private schools as corporations entered the education market, competing with public schools for government funding from vouchers. ${ }^{9}$ Consequently, there were now more schools and less funding to share than ever. Thus, instead of allowing poorer students to have access to better education, privatization and decentralization caused the stratification of schools based on socioeconomic status, the creation of a large gap in the quality of Chilean institutions, and unequal opportunities for students pursuing a university degree.

\section{Socioeconomic Stratification}

Analyzing the issue of socioeconomic stratification in Chilean schools begins with the fallacy of preference. While the introduction of vouchers was supposed to increase consumer choice and allow lower class citizens to have access to the better education often associated with private schools, fact is different than theory. In Martin Carnoy's article, "National Voucher Plans in Chile and Sweden," he points out that even when students technically have the same choice of schools, poorer families have limited options because they often lack transportation. ${ }^{10}$ Subsidized private schools appear most commonly in urban areas of the country, where wealthier families are located. Poorer families tend to live a significant distance away, either on the periphery of the city or in the rural countryside. With limited access to a reliable means of transportation, most low-income families are unable to take their

\footnotetext{
${ }^{4}$ Aleida van der Wal, "Decentralization of Education in Chile: A case of institutionalized class segregation” (master's thesis, Leiden University, 2007), 15.

${ }^{5}$ Ernesto Schiefelbein and Paulina Schiefelbein, “Three decentralization in two decades: Chile 1981-2000,” Journal of Educational Administration 38, no. 4 (2000): 6.

"The failings of Chile's education system: Institutionalized inequality and a preference for the affluent," Council on Hemispheric Affairs, July 2008, http://www. coha.org/the-failings-of-chile's-education-system-institutionalized-inequality-and-apreference-for-the-affluent/.

${ }^{7}$ Schiefelbein and Schiefelbein, "Three decentralization in two," 2.

${ }^{8}$ Council on Hemispheric Affairs, "The failings of Chile's education"

${ }^{9}$ Ibid.

${ }^{10}$ Martin Carnoy, "National voucher plans in Chile and Sweden: Did privatization reforms make for better education?” Comparative Education Review 42, no. 3 (1998): 311.
}

child to a private school many miles away. Wealthier families, however, do not face these same obstacles and tend to place greater emphasis on the quality of a school than on its location. As a result, they are more likely to use their voucher to transfer their child to a better, private institution. ${ }^{11}$

Another contributing factor to the socioeconomic stratification of the Chilean education system is the process of "creaming," in which private and private-subsidized schools can choose the criteria by which they select students; a benefit that public schools, which must accept all registered students, do not enjoy. ${ }^{12}$ Thus, non-municipal schools, now filled with the brightest, handpicked students from the wealthiest families, tend to have the best reputations-meaning more families want their students to attend. Higher and middle-income students then migrate to private and subsidized schools, bringing with them their stategiven voucher money. Lower class students, meanwhile, are relegated to municipal schools. Such creaming is evidenced by the fact that partially subsidized public schools have $7 \%$ fewer disadvantaged students than municipal schools. ${ }^{13}$ As a result, there has been a significant exodus away from Chilean public schools. In 1979, "82\% of basic school (grades 1-8) students attended public schools." 14 By the beginning of the 2011 student protests, the number had plummeted to $40 \%{ }^{15}$ Thus, the privatization and decentralization of the Chilean educational experience did not lessen the divide between the classes-it deepened it.

\section{Inequality in Education}

Not only did Pinochet's educational reforms result in socioeconomic stratification, but they also caused a significant difference in the quality of education between municipal and non-municipal schools. When the students left public schools for private schools, they brought with them a corresponding percentage of voucher subsidies, which meant that these private schools had more funds to spend on teachers, textbooks, and other important resources. ${ }^{16}$ Municipal governments, however, were often stuck with clearly inadequate supplies and inferior teachers.

Such inequality in educational resources is best measured by analyzing data from the Chilean SIMCE (Sistema de Medición de la Calidad Educacional)-a system developed in 1988 in order to assess the nation's schools and set goals for their improvement. Each year, a standardized test is given for certain grades of primary and secondary students. In Aleida van der Wal's study, "Decentralization of Education in Chile," she identifies the inequality within the Chilean education system by examining the 1999, 2002, and 2005 SIMCE for fourth graders. For both the language skills and math sections, private schools received significantly better average scores over the three years than both private-subsidized and municipal institutions. ${ }^{17}$ Good results mean a higher spot on the nation's school rankings and a potential monetary reward from the government. A high national ranking will result in more student migration to that specific school, which will mean the school receives more money from the government

${ }^{12}$ Florencia Torche, "Privatization reform and inequality of educational opportunity: The case of Chile," Sociology of Education 78, no. 4 (2005): 318.

${ }^{13}$ Gregory Elacqua, "Enrollment practices in response to vouchers: Evidence from Chile," National Center for the Study of Privatization in Education (2006): 7

${ }^{14}$ Carnoy, "National voucher plans," 318.

${ }^{15}$ Francisco Goldman, "Camila Vallejo, the world's most glamorous revolutionary," New York Times Magazine, April 2012, http://www.nytimes.com/2012/04/08/magazine/camila-vallejo-the-worlds-most-glamorous-revolutionary.html.

${ }^{6}$ Chang-Tai Hsieh and Miguel Urquiola, "The effects of generalized school choice on achievement and stratification: Evidence from Chile's voucher program," Journal of Public Economics 90, no. 8-9 (2006): 1481.

${ }^{17}$ Wal, "Decentralization of Education," 12. See Appendix for specific data.
} 
and from tuition. The school will likely repeat its success the next year, creating a cycle where the wealthiest private schools continue to steal students and funding away from the poor municipal schools. Therefore, rather than improving the quality of Chilean education, marketization prevents public schools from getting the resources they need to succeed.

\section{The Exclusivity of Education}

The final, major problem with the Chilean education system is the exclusivity and expense of higher education, evidence that the disparity in the quality of primary and secondary schools continues to affect students in their pursuit of a university acceptance letter. A comparative study analyzed the backgrounds of students enrolled at universities that were a part of the Council of University Presidents, a group of 25 publicly funded universities (16 state, 9 private). It revealed that at Chile's most prestigious university, the Pontificia Universidad Católica (PUC), 70.6 percent of students had attended private schools; 14.3 percent, subsidized schools; and $15.1 \%$, municipal schools. ${ }^{18}$ The Universidad de Chile revealed similarly concerning results, in which 50.8 percent were from private institutions; 22 percent, subsidized schools; and 27 percent, municipal schools. ${ }^{19}$ Thus, it is clear that acceptance and attendance at the nation's major colleges depends largely upon where one comes from, a clear inhibitor for those that were educated in public schools.

Another limiting factor for Chileans wishing to pursue a postsecondary degree is the high cost of the nation's universities. The average tuition for Chilean universities registered with the Council can take up almost 40 percent of a middle-class family's income, one of the most expensive educations in the world..$^{20}$ Therefore, many students cannot afford tuition. Taking out student loans does not improve their outlook either, as Chilean college students graduate with a 174 percent ratio of debt to future income. ${ }^{21} \mathrm{It}$ is this inaccessibility of a college education that so infuriated students in 2011.

\section{THE SYSTEM SURVIVES}

Despite the clearly negative impact of Pinochet's educational reforms, they have survived his fall from power, and his death, because of two main obstacles: the Constitution of 1980 and the Chilean Concertación's continuation of Pinochet's neoliberal policies. The Constitution of 1980 made Pinochet a constitutional president and created a "protected democracy" that was hardly democratic at all. It included features such as "a 'binomial' electoral system designed to make it hard for any political group to attain a clear majority in Congress; "[there is a requirement of] supermajorities (4/7 of the total members...to get congressional approval to bills relating to crucial aspects of public life, such as education, health care)." 22 The General's new "protected democracy" would make it difficult for future governments to make meaningful changes, regardless of whether or not they held a majority in Chile's Chamber of Deputies and Senate.

However, even when the Concertación, Chile's newly elected coalition, had the majority needed to make significant changes, they chose to continue many of Pinochet's problematic policies.

\footnotetext{
${ }^{8}$ Ann Matear, "Barriers to equitable access: Higher education policy and practice in Chile since 1990," Higher Education Policy 19, no. 6 (2006): 40.

${ }^{9}$ Ibid.

${ }^{20}$ Ernesto Muñoz-Lamartine, "Student leaders reinvent the protest," Berkley Review of Latin American Studies (2011-2012): 26.

${ }^{21}$ Ibid.

${ }^{22}$ Javier Couso, “Trying democracy in the shadow of an authoritarian legality: Chile's transition to democracy and Pinochet's Constitution of 1980," Wisconsin International
} Law Journal 29, no. 2 (2011): 398.

The Concertación was a coalition of center-left political parties in Chile, including prominent groups like the Socialist (social democratic) Party and Christian Democrats. It was formed in 1988 as a collaborative effort to win the 1988 Referendum, in which the nation voted against an eight-year extension of General Pinochet's rule. The coalition won the subsequent election of 1990 and would remain in power until 2010, when rightist President Sebastián Piñera was elected. The Concertación gained the presidency by promising social change-income redistribution, improved labor standards, and recognition of the regime's oppression-and the return of the civil liberties that had been repressed under Pinochet. However, prior to the national election, the coalition's candidate, Patricio Aylwin, emphasized, "the last thing they intend to do is damage the successful free-market economy fostered by the Pinochet Government." ${ }^{23}$ The future president also made it clear that there would be "no dramatic changes to the country's social structures." ${ }^{24}$ In an effort to make a smooth transition into democracy, various presidents of the Concertación, beginning with Aylwin, made concessions to avoid conflict and restricted their political planning to fit the institutional structures already in place, both examples of "consensus building." 25 Thus, Pinochet's neoliberal policies remained standing. Little progress was made in labor and income redistribution. Pinochet's Amnesty Law, which prevented many of the worst human rights violators from being prosecuted, remained intact. The ruling coalition failed to meet the demands of the "disappeared" victims and their families, causing the Organizing Committee of Former Political Prisoners to claim, "Impunity has become an integral part of a society shaped by the dictatorship, in which the perpetrators, those who benefited from the crimes, those who occupied leading positions during the dictatorship, and current government officials can feel comfortable." ${ }^{26}$ Therefore, it is no surprise that the Concertación had made little effort to change Chile's faulty education system, a claim that is evidenced in part by the survival of the 1990 Ley Orgánica Constitucional de Enseñanza (LOCE), which Pinochet passed on his last day in office. It formalized his educational reforms by providing the legal basis for decentralization and privatization. While minor reforms would be made in the future, the survival of the LOCE demonstrated the Concertacion's dedication to the status quo-one that would remain unchallenged until 2006, when a student movement would hold the nation's rapt attention for seven months.

On May 21, 2006, President Michelle Bachelet delivered her annual address to the Chilean people: "Let me be crystal clear... [w] hat we have witnessed over recent weeks is unacceptable. I will not tolerate acts of vandalism or intimidation. I will apply the full force of the law."'27 Bachelet was addressing the beginnings of the "Penguin Revolution," the 2006 Chilean secondary student movement that began in late April and was one of the first significant democratic demonstrations since the end of Pinochet's regime. Led by the Coordinating Assembly of High

\footnotetext{
${ }^{23}$ Shirley Christian, "Goal in Chile: Fiscal change with stability," New York Times, August 28, 1989.

Marcus Taylor, From Pinochet to the 'third way': neoliberalism and social transformation in Chile (Ann Arbor: Pluto Press, 2006), 113.

5 "The tradeoff of labor and neoliberal economics: The case of Chile in the 1990s," Council on Hemispheric Affairs, August 2011, http://www.coha.org/the-tradeoff-oflabor-and-neoliberal-economics-the-case-of-chile-in-the-1990s/.

${ }^{26}$ Ana Ros, The post-dictatorship generation in Argentina, Chile, and Uruguay: Collective memory and cultural production (New York: Palgrave Macmillan, 2012), 120 .

Michelle Bachelet in Orlando Sepúlveda, "Biggest mass movement since Pinochet: Chilean students launch mass protests,” International Socialist Review 49 (2006).
} 
School Students (ACES), the students' demands began relatively simply: free transportation passes and the removal of university admission exam fees. However, Bachelet's comments and failure to engage the students in negotiations caused the movement to grow explosively. Fueled by its $76 \%$ approval rating and new, more complex aspirations; "the student struggle subsequently shifted to focus on the poor quality and high inequality of Chilean education in terms of attainment, quality, resources, and opportunities." 28 The students' slogan, "Be realistic. Demand the impossible," matched their newly ambitious goals, which included ending the controversial LOCE and the excessive marketization of their education..$^{29} \mathrm{~A}$ turning point in the protests came in late May when the Chilean national police-or los carabineros-attacked marching students. The police beat them, used tear gas canisters on them, and sprayed them with water cannons. As a result, the "Penguins," so named after their black-and-white uniforms, gained further popular support and forced Michelle Bachelet to the negotiating table.

In the wake of the police brutality against the protestors, eerily reminiscent of the repression under General Pinochet, President Bachelet released the head of the police special forces, offered to reform the LOCE, and "announced a \$135-million-a year package that includes a free lunch program for the poorest students, the repair or renovation of up to 1,200 public schools and elimination of the $\$ 40$ college exam fee." ${ }^{30}$ The students, however, rejected the offer, claiming that it was not enough. What they failed to realize was that they had reached their peak popularity. As the movement continued, its strict organization began to break down, internal divisions developed, and public support waned. The students officially returned to class at the end of June 2006. While it had failed to enact significant change, the movement openly challenged the Concertación's continuation of Pinochet's neoliberalism and fought for fundamental structural change. The students brought the Chilean education system to the forefront of the national agenda and set the stage for the 2011 student movement to take the nation by storm.

\section{A NEW REVOLUTION}

Five years later, Chilean students would again take to the streets in the name of education. This time, however, they got creative. They held "kiss-ins" where students kissed in front of La Moneda for 1,800 seconds, representing the $\$ 1.8$ billion supposedly needed to finance public education. ${ }^{31}$ They dressed up as superheroes, performing a choreographed dance and fake battle scene; they staged fake deaths, where everyone would fall to the ground at the same time; and they organized marches and school-takeovers. As these students fought for equality with their various performances, their passion and determination captured international recognition and inspired their countrymen to support the movement.

These students were led by the united Chilean Student Confederation (CONFECH); Camila Vallejo, president of the Student Federation of the University of Chile (FECH), and Giorgio Jackson, president of the Student Federation of Catholic University (FEUC), acted as the movement's most influential leaders. Initially, the protesters focused on getting more resources for public schools and improving access to universities for lower-income individuals;

\footnotetext{
${ }^{28}$ Cristián Bellei and Cristian Cabalin, "Chilean student movements: Sustained struggle to transform a market-oriented educational system," Current Issues in Comparative Education 15, no. 2 (2013): 112.

${ }^{29}$ Larry Rohter, "Chilean promised a New Deal; Now striking youth demand it," New York Times, June 2006, http://www.nytimes.com/2006/06/05/world/ americas/05chile.html.

${ }^{30}$ Ibid.

${ }^{31}$ Goldman, "Camila Vallejo."
}

however, as the movement expanded and became more politicized, the students began to demand structural changes. They were furious with the socioeconomic stratification and inequality that was so prevalent in their schools and society, and "their discourse reflected notions of social justice in education, by rejecting the subsidiary role of the state in education, promoting universal non-discriminatory access to free education, and requesting progressive tax reform to publicly fund education." 32 President Piñera not only failed to adequately address the movement, but he also attempted to subvert the protestors by convincing the Chilean population that the reform the students wanted was not feasible. ${ }^{33}$ This was in addition to his controversial crowd management techniques, in which police met marching students with tear gas, water cannons, and beatings. The students, however, persevered and used the drastic measures taken by los carabineros to their advantage. For example, after a particularly violent rally, Vallejo and other students collected tear-gas shells and formed them into a peace sign on the ground in front of La Moneda. As Vallejo kneeled in the middle of the powerful symbol, she announced to the journalists surrounding her, "Here are more than 50 million pesos worth of tear-gas bombs'... money...that could have been spent on education." ${ }^{34}$ Powerful images, such as that of Vallejo crouched in the peace sign, helped build the student movement's momentum, putting it in a position to succeed in a way that the 2006 students could only have dreamed.

Piñera, after his government finally came to the negotiating table, would make the students multiple offers, each of which was rejected as insufficient by the movement's leaders. As a result, the protestors continued to cause his government significant trouble. Two Ministers of Education resigned during the protests and Piñera's approval ratings plummeted to a historically low 22 percent. ${ }^{35}$ The students wanted more than the promise of policy from Piñera; they wanted a revolution in higher education.

While they never extracted satisfactory concessions from the president, the 2011 Chilean Winter dramatically altered the nation's political landscape. The student movement forced education reform to the forefront of the nation's agenda; Bachelet won the 2013 presidential race under the banner of education reform, and four student leaders, including Vallejo and Jackson, were elected to Congress. In 2015, Bachelet took an important step towards making good on her electoral promises when she signed a law that would "gradually ban profits, tuition fees, and selective admissions practices in privately-owned primary and secondary schools that receive state subsidies." ${ }^{36}$ The statute came after the president raised the Chilean corporate tax to increase the education budget, a policy that reformers had been pushing for throughout the 2011 movement. Although the Chilean students were not yet satisfied, a common theme in the nation's politics, Bachelet's changes were an important victory in education and showed the dramatic effect that the 2011 protests had had on politics in Chile. In 2016, Bachelet was able to announce the Gratuidad 2016 [Gratuity 2016] program in which "tuition will be free for half of the students from the 50 percent poorest families." 37 She plans to continue expanding the policy into 2020, a victory for Chilean students that shows that the Penguin Revolution's saying:

\footnotetext{
${ }^{2}$ Bellei and Cabalin, "Chilean student movements," 115

${ }^{33}$ Camila Vallejo, Podemos cambiar el mundo (Chile: Ocean Sur, 2012), 10.

${ }^{34}$ Camila Vallejo in Goldman, "Camila Vallejo."

35 Ibid.

${ }^{36}$ Emily Achtenberg, "Chilean students struggle to deepen educational reforms," North American Congress on Latin America, June 2015, https://nacla.org/blog/2015/03/03 / chilean-students-struggle-deepen-educational-reforms.

Maria Hurtado, "Free tuition for students from 50\% poorest families," UniversityWorldNews, January 2016, http://www.universityworldnews.com/ article.php?story=20160106154515871
} 
"Be reasonable. Demand the impossible," was not as contradictory as it seemed.

\section{A PROTEST AGAINST INACTION}

When analyzing a movement such as the 2011 Chilean Winter, which played such an extensive role in the eventual restructuring of the nation's education system, it is necessary to examine what caused such an impactful force to develop. To do so, one must differentiate between protests against the legacy of the Pinochet reforms-that is, the maintenance of his negative policies in the current systemfrom protests against the policies themselves. That is to say, the student movement was not concerned with the establishment of Pinochet's neoliberal education system, but with the fact that the system remained unchanged even after the nation had transitioned into a democracy. Most, if not all, of the 2011 student protestors were born too late to remember or experience Pinochet's rule. They were a different generation destined to play a different role than their parents, a sentiment that Mexican journalist Rafael Gumucio acknowledges in his magazine profile of student leader Giorgio Jackson: "aquí son los padres los nihilistas, los suicidas, los acallados, los frustrados, y los hijos los reformistas, los relistas, los estrategas" [here the fathers are the nihilists, the suicides, the silenced, the frustrated, and the sons are the reformers, the realists, the strategists]. ${ }^{38}$ The protestors, with little personal connection to the General, were focused more on changing the future than the past. Thus, there is little mention of Pinochet in the movement's revolutionary discourse. When student leader Giorgio Jackson was questioned about what the dictatorship meant to him, he promptly responded "Nothing. I was born in 1987." 39 In her collection of interviews and speeches, Podemos cambiar el mundo [We can change the world], student leader Camila Vallejo mentions the dictatorship in only a few minor instances; for example, "tenemos una Constitución política heredada de la dictadura" [we have a political Constitution inherited from the dictatorship $].{ }^{40}$ Thus, while the movement identified the General's reforms as the root of the education problem, they were not protesting these policies.

What the students were protesting, as their rhetoric demonstrates, was the failure of the Concertación and Piñera governments to make the structural changes necessary to rid Chile of Pinochet's harmful educational programs. The Chilean Winter's frustration with the state's perpetuation of a broken system is best articulated through the stinging criticisms of Camila Vallejo; in Podemos cambiar el mundo, she claims that the government "no ha logrado en más de treinta años disminuir los graves problemas de desigualidad e injusticias sociales...solo ha conseguido profundizarlos" [has not succeeded in more than 30 years to lessen the grave problems of inequality and social injustices...it has only continued to make them deeper]. ${ }^{41}$ She attacks Chilean leaders, particularly those of the center-left Concertación, for repeatedly and selfishly putting private monetary interests before those of the people, as demonstrated by the state's maintenance of the neoliberal, privatized status quo, which brought Chile economic growth but also dramatic inequality. ${ }^{42}$ Vallejo, however, was at least willing to negotiate with Concertación officials. Many students were against any interaction with the coalition; in fact, in Vallejo's quest for re-election as president of the FECH, her talks with the Concertación were used against her. New York Times journalist Francisco Goldman explains that, even though every

\footnotetext{
${ }^{8}$ Rafael Gumucio, "Padres nihilistas, hijos realistas," Gatopardo, March 2013, http://www.gatopardo.com/reportajes/padres-nihilistas-hijos-realistas/.

${ }^{39}$ Goldman, "Camila Vallejo."

${ }^{40}$ Vallejo, Podemos cambiar el mundo, 13.

${ }^{41}$ Ibid., 129.

${ }^{2}$ Ibid., 16
}

leader after Pinochet (except the recently elected Piñera) had been from the Concertación, nothing had changed. ${ }^{43}$ Thus, the student movement had come to associate the coalition with the rest of Chile's rich and powerful, all of whom greedily searched for ways to build their fortunes and refused to put the public's needs above their own.

However, it was the actions of the rightist government of Sebastián Piñera that would provide the final match needed to light the 2011 Chilean Student Movement's revolutionary fire. Piñera's first Minister of Education, Joaquín Lavín, proposed increasing government aid to private universities, an action that wrought a furious response from Chilean students. In a scathing address to Lavín, Vallejo asks the Minister how he can pretend that the continuation and support of a privatized and market-based education system helps Chile, claiming that these actions have caused, among other problems, "el enriquecimiento de unos pocos a costa de la educación de muchos; el endeudamiento excesivo de los jóvenes y sus familias; la falta de democracia al interior de las instituciones," [the enrichment of few at the cost of education to many; the excessive indebtedness of youth and their families; the lack of democracy in the interior of the institutions $]{ }^{44}$ While previous governments had done nothing to change the education system, most had avoided having to defend it, focusing instead on the economic benefits that neoliberalism had brought to Chile. Piñera, however, defended the market-based education system by claiming education was a "consumer good," a comment that only fueled the movement's fury. Furthermore, the president made few efforts to work with the student movement; in a description of a meeting she had with Piñera and his Minister of Education, Vallejo characterized the two as disinterested and unprepared. Despite arranging the meeting, the two failed to make any concrete proposals. ${ }^{45}$ Coupled with his attempts to repress the student movement, Piñera's general disrespect for the protestors and their aspirations demonstrates the major issue Vallejo and the Chilean Winter had with their nation's government-no one wanted to challenge the status quo, even if it continued to hurt the Chilean people. Only a powerful, nationally united movement could enact such a change, and so it did.

\section{CONCLUSION}

Pinochet's decentralization and privatization of the Chilean education system was representative of the neoliberal rule that characterized Latin American history at the time. However, more than 30 years after the reforms were enacted, Pinochet's policies had survived even as neoliberalism had faded from the region. The Chilean people paid a steep price: the socioeconomic stratification of the education system, the unjust differences in the quality of education between private and public schools, and the exclusivity of the nation's post-secondary educational institutions. Thus, when the 2011 Chilean student movement began, one could have logically connected its origins to Pinochet's reforms. The protesters, however, remained remarkably focused on their present situation, not questioning Pinochet, but instead questioning why, even after the nation had transitioned into a democracy, the dictator's poisonous education policies remained standing. The fiery rhetoric of student leader, Camila Vallejo, repeatedly criticized the Concertación coalition and Piñera government, working to force the nation to change its educational structure. She, and the other students involved, repeatedly emphasize that the 2011 Chilean Winter was not an isolated, sudden incident. It had been building over 30 years as politics and economics repeatedly blocked reformation. It was not a phenomenon. It was a revolution.

\footnotetext{
${ }^{3}$ Goldman, "Camila Vallejo."

${ }^{44}$ Vallejo, Podemos cambiar el mundo, 101

${ }^{45}$ Ibid., 42
} 


\section{AUTHOR INFORMATION}

All correspondence should be sent to the first author:

pickettsam6@gmail.com

\section{REFERENCES}

Achtenberg, Emily. "Chilean students struggle to deepen educational reforms." North American Congress on Latin America, June 2015. https://nacla.org/blog/2015/03/03/ chilean-students-struggle-deepen-educational-reforms.

Bellei, Cristián and Cristian Cabalin. "Chilean student movements: Sustained struggle to transform a market-oriented educational system." Current Issues in Comparative Education 15, no. 2 (2013): 108-123.

Carnoy, Martin. "National voucher plans in Chile and Sweden: Did privatization reforms make for better education?" Comparative Education Review 42, no. 3 (1998): 309-337.

Christian, Shirley. "Goal in Chile: Fiscal change with stability." New York Times, August 28, 1989.

Collyns, Dan. "Bachelet pledges radical constitutional reforms after winning Chilean election.” The Guardian. December 2013. http://www.theguardian.com/world /2013/dec/ 16/chilepresident- elect-michelle-bachelet-election-reforms.

Couso, Javier. "Trying democracy in the shadow of an authoritarian legality: Chile's transition to democracy and Pinochet's Constitution of 1980." Wisconsin International Law Journal 29, no. 2 (2011): 394-415.

“The failings of Chile's education system: Institutionalized inequality and a preference for the affluent." Council on Hemispheric Affairs. July 2008. http://www.coha.org/thefailings-of-chile's-education-system-institutionalized-inequalityand-a-preference-for-the-affluent/.

Elacqua, Gregory. "Enrollment practices in response to vouchers: Evidence from Chile." National Center for the Study of Privatization in Education (2006).

Goldman, Francisco. "Camila Vallejo, the world's most glamorous revolutionary.” New York Times Magazine. April 2012. http:// www.nytimes.com/2012/04/08/magazine/ camila-vallejo-theworlds-most-glamorous -revolutionary.html.

Gumucio, Rafael. "Padres nihilistas, hijos realistas." Gatopardo. March 2013. http://www.gatopardo.com/reportajes/padresnihilistas-hijos-realistas/.

Hsieh, Chang-Tai and Miguel Urquiola. "The effects of generalized school choice on achievement and stratification: Evidence from Chile's voucher program." Journal of Public Economics 90, no. 8-9 (2006): 1477-1503.

Hurtado, Maria. "Free tuition for students from 50\% poorest families.” University WorldNews, January 2016. http://www. universityworldnews.com/article.php?story=20160106154 515871.

Matear, Ann. "Barriers to equitable access: Higher education policy and practice in Chile since 1990." Higher Education Policy 19, no. 6 (2006): 31-49.

Muñoz-Lamartine, Ernesto. "Student leaders reinvent the protest." Berkley Review of Latin American Studies (2011-2012): 25-30.
Reuters. “Chile Thriller Protest.” Filmed [June 2011]. YouTube video, 1:06. Posted [June 2011]. https://www.youtube.com/ watch?v=sVjqtxGr1nY.

Rohter, Larry. "Chilean promised a New Deal; Now striking youth demand it.” New York Times. June 2006. http://www.nytimes. com/2006/06/05/world/americas/05chile.html.

Ros, Ana. The post-dictatorship generation in Argentina, Chile, and Uruguay: Collective memory and cultural production. New York: Palgrave Macmillan, 2012.

Schiefelbein, Ernesto and Paulina Schiefelbein. "Three decentralization strategies in two decades: Chile 1981-2000.” Journal of Educational Administration 38, no. 4 (2000).

Sepúlveda, Orlando. "Biggest mass movement since Pinochet: Chilean students launch mass protests." International Socialist Review 49 (2006).

Taylor, Marcus. From Pinochet to the 'third way': neoliberalism and social transformation in Chile. Ann Arbor: Pluto Press, 2006.

Torche, Florencia. "Privatization reform and inequality of educational opportunity: The case of Chile." Sociology of Education 78, no. 4 (2005): 316-343.

"The tradeoff of labor and neoliberal economics: The case of Chile in the 1990s." Council on Hemispheric Affairs. August 2011. http://www.coha.org/the-tradeoff-of-labor-and-neoliberaleconomics-the-case-of-chile-in-the-1990s/.

Vallejo, Camila. Podemos cambiar el mundo. Chile: Ocean Sur, 2012.

Wal, Aleida van der. "Decentralization of education in Chile: A case of institutionalized class segregation.” Master's thesis, Leiden University, 2007.

\section{APPENDIX}
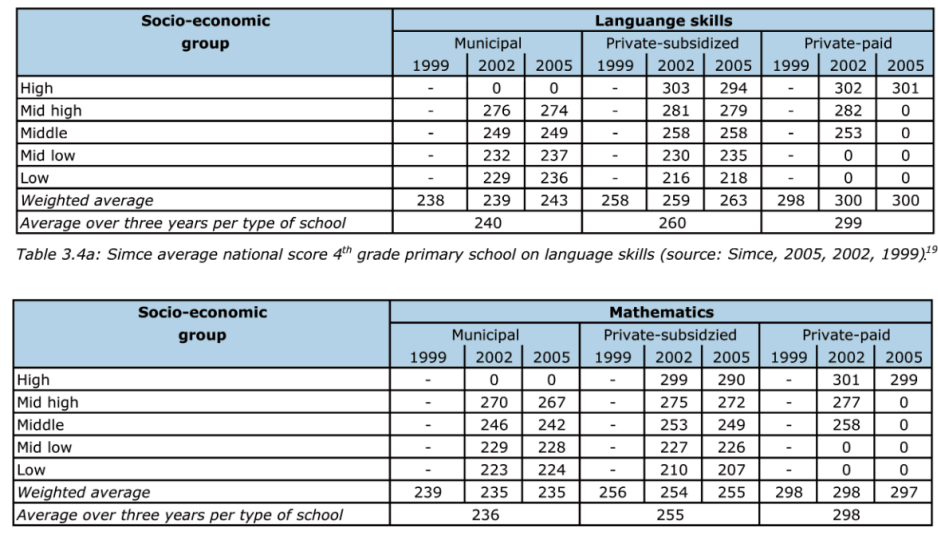

Table 3.4b: Simce average national score $4^{\text {th }}$ grade primary school on mathematics (source: Simce, 2005, 2002, 1999).1.5 